\title{
Foreword by the Vice-Chancellor of The Open University
}

On 23 April 1969, the day The Open University came into being, our founding Chancellor Geoffrey Crowther set out his vision for the institution. It was a vision that went on to become our core ethos: to be open to people, places, methods and ideas.

Since then, we have continually strived to emulate Crowther's ideals. The OU has become the UK's largest university. The National Student Survey repeatedly ranks us at the forefront of British higher education. We dominate provision for part-time students. We offer access to higher education for people from economically or socially disadvantaged backgrounds. We're home to more students with disabilities than any other university. We have played a significant role in the development and expansion of prisoner education. We have pioneered the provision of free online courses. And our co-productions with the BBC are seen and heard by millions of people around the world every year.

Hundreds of thousands of people have studied with The Open University, with countless more people in their families, communities and places of work also feeling the benefits. Still more will have been educated elsewhere by teachers and lecturers who honed their academic skills here or began their studies with us. But the impact of The Open University has always gone beyond individuals. Since Harold Wilson first proposed a 'university of the air' in his 1963 'white heat' speech, The Open University has also had a central role to play in the continuous transformation of higher education.

When the university's first mailings were being dispatched in 1971, the Secretary of State for Education was Margaret Thatcher. In the decades that have followed, the world in which we live, work and study has changed beyond all recognition. There have been constant shifts in the cultural, technological and political context in which all universities operate and - as a practical laboratory of university education - The Open University has been both a subject and an agent of that change. Today it is at the heart of the 
debate about the future of higher education in the digital age, leading the UK's top universities into the world of Massive Open Online Courses.

At The Open University we have always looked to the future. But if we are going to continue the progress we have made since 1969, we must also take stock of where we are, remember where we have come from, and understand how we overcame the challenges and critics we encountered along the way. We have to grasp how, in just a few short years, The Open University made the transition from an 'electoral gimmick' (to quote one politician of the time) to its current status of 'national treasure' (in the words of the Vice-Chancellor at another university). The benefits of this historical perspective will also be felt further afield, as those who seek a greater understanding of the power of education will be able to learn from our experiences, our mistakes and our successes.

The Open University has been holding degree ceremonies for graduates since 1973, when the first was broadcast live on television from Alexandra Palace. In the years since then, ceremonies have been held across the UK and around the world, online and even in prisons.

While each degree ceremony is unique in its own way, all have a common theme. They're a very real representation of the values that Geoffrey Crowther laid out all those years ago, of our ongoing commitment to innovative, topquality higher education that is open to all. And they're a reminder that central to the history of The Open University is the story of how an institution that many said could never succeed has done so much to help so many achieve what they once thought impossible.

Martin Bean

February, 2014 